\title{
THE ROLE OF THE MATERIALITY IN AUDIT AND ACCOUNTACY IN AGRICULTURAL ORGANIZATIONS
}

\author{
Sorina Simona Bumbescu ${ }^{1}$ \\ Dimi Ofileanu ${ }^{2}$ \\ Raul Burdea ${ }^{3}$
}

\begin{abstract}
In this article it is realised an overview of the importance that the materiality has for the audit and the accountancy activity, beeing an interdependence relationship between the information provided by the accountancy and audit activity. Based on previous studies concerning the materiality, in this article it is developed a synthetic theoretical framework regarding the materiality, the relationship between materiality and audit risk, the steps that heve to be made in order to determine the materiality, and ultimately it is realised a case study concerning the calculation and analysis of the materiality in an agriculture entity. The research leads to two major categories of tangible results; on the one hand it is realised a qualitative theoretical synthesis on materiality, on the other hand, it exemplifies the calculation and analysis of materiality, and last but not least it highlights the importance of determining the materiality for the activity of any organization.
\end{abstract}

Keywords: materiality, audit risk, auditor, error

JEL Codes: M41, M42

\section{Introduction}

The information presented in the financial statements in order to have a high level of confidence for external users it is necessary an audit in acordnace with the specific regulations. The accounting information from the financial statements, their qualitative characteristics are the central point to carrying out audit procedures and thus to determine the materiality.

At the beginning of the mission, setting a global materiality it is necessary in order to determinate the significant areas and systems. As a result, to estabilish a materiality allows: better mission planning ; avoiding unnecessary works; justify the decisions on the opinion issued.

Estabilishing a materiality allows the auditor from the beginning of its mission to appreciate better the systems and accounts that can contains errors or significant inexactness, and at the end of the mission to determine whether the anomalies that were founded must to be corrected in order to be able to issue an unqualified opinion. The preliminary materiality it is estabilished in the first phase of the mission and is constantly reviewed during the development of an audit mission and can be modified if the auditor discovers the information which would led to initially establish a different value.

Regarding the significant elements and materiality, audit standards do not give a percentage or absolute monetary estimate and does not indicate a universally applicable mathematical method. Establishing the significant elements and the materiality is left by those standards to the auditor appreciation, due to the large number of factors who must be considered and their subjective relative importance.

\footnotetext{
1 “1 Decembrie 1918” University, Alba Iulia, Romania, e-mail: sorina.bumbescu@gmail.com

2 “1 Decembrie 1918” University, Alba Iulia, Romania,e-mail: dimi_ofileanu@yahoo.com

3 “1 Decembrie 1918” University, Alba Iulia, Romania, e-mail: raul_burdea@yahoo.com
} 
The general objective of this paper is to highlight the importance of materiality determining for the audit and the accounting activity through the realization of a theoretical and practical synthesis useful and relevant for the users of financial statements.

The specific objectives of this article can be summarized as follows:

$>$ general outline of materiality from the perspective of the conceptual approach, its elements and the specific factors that influence the size of the materiality;

$>$ highlighting the relationship between materiality and audit risk;

$>$ presentation of the stages that must be completed in order to determine the materiality; achieving a case study on the calculation and analysis of materiality in an agriculture entity

\section{Research metodology}

In order to achieve the objectives formulated on the topic, the study is based on certain methods of scientific research. The fundamental aim of the methodology is to help us understand, in the broadest possible terms, the process of knowledge.

Any scientific research must have a purpose. This research has a dual purpose: on the one hand, to present a theoretical framework on the role of materiality in auditing and accounting and, on the other hand, to provide a case study example regarding its calculation in an agriculture entity.

The research methodology used in this article combines the qualitative research with the quantitative research. In the first parts it is provides a theoretical overview of the current state of knowledge, identifying the semnificaticve areas and systems, the materiality overall, the relationship between materiality and audit risk, the method of determining materiality. As a main research technique it is used literature review process, documentation in the relevant literature, study of International Standards of Auditing, different audit works, various articles.

In order to capture the interactions between the various elements and obtaining information on the subjects resorted is is used the case study, data analysis. The aims is to determine and analyze the materiality in an agriculture organization.

This paper aims is to study the role and importance of materiality, both theoretically as well as practically. In this study are used research methods as documenting, comparison, analysis, synthesis, in order to achieve the proposed objectives.

\section{Significant systems and areas}

For better orientation and planning of the efforts, to avoid unnecessary work and planning the opinion issued, the auditor should identify the significant areas and systems, the auditor's risk and to determine their relative importance. Since the beginning of his approach, the auditor should identify the significant areas that can contains errors, inaccuracies or can have a significant influence on the financial statements. It is considered as significant anything that may have influence on the financial statements and their users.

The significant areas include significant systems and significant accounts. The significant systems refers to those systems that provide recording and transcription of repetitive operations when their value is significant in relation to the financial statements. In general, the significant systems of an entity include: purchases, sales, personal, payments, treasury-stock production. Each of these systems must be analyzed according to the characteristics of the entity, as these systems are not significant in each entity. For example in the organization of trade, the production is not a significant system.

The significant accounts refers to those who have an important value in the financial situations or those which may hide errors, inaccuracies significant and affecting the regularity of accounting, significantly influence the financial statements.

The auditor may make significant findings throughout the financial year or in the studies of preparation of the annual accounts: evaluation, presentation or verification. 
The information are considered as significant if its omission or misstatement could influence the users economic decisions taken on the basis of the financial statements.

\section{General considerations on materiality}

In the literature there are various conceptual approaches on materiality. Auditing Standard 320 defines the materiality as"the size of an amount over which the auditor believes that an error, an inaccuracy or omission can affect both regularity and sincerity of annual accounts and trusty image of the result, the financial situation and the assets of the business.

In the "General framework for the preparation and presentation of financial statements" of the International Accounting Standards Committee, the materiality is defined by the following terms: "Information are semnificative if their omission or misstatement could influence the economic decisions of users taken based on the financial situations. The materiality depends on the size of the item or error, judged in the particular circumstances of its omission or wrong statements. Thus, the materiality provides rather a limit than to represent a primary qualitative characteristic which information must have in order to be useful.

Through the materiality we understands the importance of an omission or a misrepresentation of the financial information that gives rise to a probability that the judgment of a reasonable person who is relying on that information to be changed or influenced by that omission or error. (Bunget, 2010).

The functional materiality represents the amounts set by the auditor at a lower level than the materiality for the financial statements as a whole, in order to reduce to an appropriately low level the probability that the uncorrected misstatements or undetermined to exceed the materiality for the financial statements as a whole "(Popa et al, 2010).

The auditor considers the materiality for overall financial situations but also in the relation to the balances, with the transactions and presented information. In a first phase, the auditor should determine a general materiality for a good orientation and mission planning. In the end of the mission, if there is an overflow of global materiality, the auditor proposes to correct the errors or will mention it in the report the errors.

In order to determine the materiality are used different reference elements such as: equity, net result, turnover. These elements are known as the references bases, compared with the materiality is determined in absolute or relative values.

The findings of the auditor can influence:

$>$ outcome of the exercise. It is used as reference base the net result but if its size is less important, could be changed to another reference bases, such as the operation result or the ability to finance itself. It is important to give a particular importance to the exceptional items that will be regrouped so as to cover only the current financial year. The auditor should fiind out information about the previous net results for not taking as reference base an abnormal net results;

$>$ ways of presenting the balance sheet. The findings resulting from an incorrect classification of accounts or an unjustified compensation between debtor and creditor balances. If two bank accounts, one lender and one borrower, are offset the importance of compensation is determined by comparing it to all those stations.

The specific elements of the materiality are (Botez, 2012):

$>$ the needs of annual accounts users. The annual accounts provides information for different user: shareholders, associates, staff, creditors, tax authorities, customers, etc. Depending on the needs of users, the auditor will estabilish the materiality because the users are fixing as significant elements different elements.

$>$ enterprise characteristics. The characteristics that may be significant for materiality are: the sector of activity, size of the organization, development organization in time, socioeconomic environment in which it operates. 
$>$ the characteristics of the elements considered significant are: sensitivity, degree of approximation, the item evolution, cumulation of more items.

The factors that influence the size of the materiality are: professional judgment; customer knowledge and understanding of specific risks; the important for users who make decisions based on financial statements; the auditor experience with that client; customer history (was audited or not, what opinion was issued).

\section{The relation between materiality and audit risk}

There is an inverse relationship between materiality and audit risk level, so that the higher the materiality level is, the lower the audit risk is and vice versa. For example, if, after planning the specific audit procedures, the auditor determines that the acceptable materiality level is lower, audit risk is increased. Auditor would compensate either:

$>$ reducing the risk control and maintaining a low level by carrying out extended or additional tests of controls;

$>$ reducing the detection risk by modifying the nature, timing and extent of planned audit.

It is necessary to distinguish between the concept of uncertainty and risk. So the uncertainty means ignorance of the possibility of knowledge of events but knowledge of possible events. The risk involves ignorance with certainty of the characteristics of a future event but knowing the probabilities of occurrence of possible alternatives.

The informational risk has an important role in analyzing and determining the materiality so that the main causes of informational risk can be summarized as follows: the large volume of information, complex commercial transactions, the gap between information and users of information. Large entity reduce information risk by: auditing financial statements, assuming informational risk of management, by the users of financial statements, verification of information by financial statement users.

The audit risk is the risk that the auditor gives an inappropriate audit opinion when the financial statements are material misstatement. The audit risk has three components: inherent risk, control risk and detection risk (Toma, 2009):

$>$ inherent risk refers to the susceptibility that an account balance or class of transactions to contain a considerable material misstatement that there were no related internal controls;

$>$ control risk is the risk that a material misstatement that could occur in an account balance or class of transactions, can not be prevented and corrected by the accounting and internal control system;

$>$ detection risk is the risk that an auditor's procedures will not detect a material misstatement that exists in an account balance or class of transactions.

The auditor have to identify and assess the risks of material misstatement in the financial statements as well as in the assertions for classes of transactions, account balances and information presentation.

The auditor have to use the professional judgment to assess audit risk and to estabilish audit procedures in order to make sure that the risk is reduced to an acceptably low level. Audit risk can't be more than $10 \%$.

The auditor's assessment of materiality in relation to account balances and classes of transactions, helps the auditor decide aspects regarding what items to examine and whether to use sampling and analytical procedures. This enables the auditor to select the audit procedures that combined are expected to reduce the audit risk to an acceptably low level.

The auditor's assessment of materiality and audit risk at the initially planning of the engagement can be different from when are evaluating the results of audit procedures. In audit planning stage, the auditor may be intentionally set a lower levels of materiality than is intended to be used in evaluating audit results, in order to reduce the probability of material misstatement and to 
provide the auditor a margin of safety when are evaluating the effects of discovered misstatements during the audit proces.

The more the total of uncorrected information approach to the materiality level, the auditor considers reducing the risk by implementing additional procedures or requires management to make adjustments in the financial statements associated with wrong information detected. If the auditor believes that misstatements can be significant, then he should consider reducing audit risk by extending audit procedures or to request management to adjust the financial statements. If management refuses to adjust the financial statements and the results of extended audit procedures do not enable the auditor to conclude that the aggregate of uncorrected misstatements is not significant, the auditor should consider the appropriate modification of the auditor's report.

\section{Materiality determining}

In order to determine the materiality must be consider some particular circumstances: the existence of legal aspects, statutory or contractual; evolution from one year to another of some aspects; equity or abnormal results.

There are two phases and five steps necessary to estimate the materiality based on analysis of significant areas (Domnişoru, 2011):

Phase 1: Planning the test, which includes two steps:

$>$ fixing preliminary value of the materiality

alocated the preliminary value of the materiality

Phase 2: Evaluation of the results, which includes three stages:

estimating the total misrepresentation of the segment

$>$ estimate the cumulative value of the misrepresentation

comparing the estimated cumulative value with the preliminary or revised materiality

The preliminary value of materiality is the maximum amount in the auditor's opinion of the misrepresentations that could contain financial statements, without affecting users' decisions.

Based on professional judgment is considered that:

$>$ cumulation of errors in financial statements presentation which exceed $10 \%$ is considered significant;

$>$ under 5\% is assumed to be insignificant in the absence of some qualitative influence factors;

between $5 \%$ and $10 \%$ is necessary to use professional judgment in order to determine if errors have significant character.

The materiality is determined usually as a percentage that is applied to the reference base being considered intervals, as shown in table no. 1. January. The materiality level is set usually between the smallest and largest value of the calculated factors.

The reference bases applicable to the materiality

\begin{tabular}{|c|c|c|}
\hline No. & Calculation reference & $\begin{array}{c}\text { Percentage } \\
(\%)\end{array}$ \\
\hline 1 & Total assets & $1 \%$ \\
\hline 2 & Total assets & $2 \%$ \\
\hline 3 & Turnover & $0,5 \%$ \\
\hline 4 & Turnover & $1 \%$ \\
\hline 5 & Gross profit & $5 \%$ \\
\hline 6 & Gross profit & $10 \%$ \\
\hline
\end{tabular}

Source: Sorin Domnişoru, 2011, p. 217

Table no. 1 
The materiality in audit tends to be as low as possible due to the special interest in performance issues, legality and regularity, morality, etc.

It is generally accepted that if: the materiality level is lower than the errors, the accounts are not accepted; the materiality level is higher than the error, the accounts are accepted; the materiality level is close to the errors found, increase the sample size.

\section{Case study on the determination of materiality}

In order to illustrate the theoretical concepts presented above, we propose to calculate and analyze the materiality to an organization who is acting in agriculture, audited by Audit LLC for 2011. Some of the financial information are summarized in table. 2.

The main financial information necessary to determine the materiality

Table no. 2

\begin{tabular}{|l|c|c|}
\hline \multicolumn{1}{|c|}{ Indicators } & $\begin{array}{c}\mathbf{3 1 . 1 2 . 2 0 1 1} \\
\text { (in lei) }\end{array}$ & $\begin{array}{c}\mathbf{3 1 . 1 2 . 2 0 1 2} \\
\text { (in lei) }\end{array}$ \\
\hline Fixed assents & 63.895 & 59.618 \\
\hline Current assets, from which: & 192.311 & 497.170 \\
\hline$>$ stocks & 25.042 & 72.309 \\
\hline$>$ receivable & 156.240 & 417.064 \\
\hline \multicolumn{1}{|c|}{$>$ liquid assets } & 11.029 & 7.797 \\
\hline Total assets & 256.206 & 556.788 \\
\hline Liabilities & 204.746 & 437.901 \\
\hline Equity & 71.700 & 130.276 \\
\hline Turnover & 715.269 & 757.182 \\
\hline Sales cost & 668.467 & 687.232 \\
\hline Gross profit & 46.802 & 69.950 \\
\hline
\end{tabular}

Source: financial statements of the organization

In the phase of planning of the audit engagement it is determine a preliminary level of materiality which will be reviewed during the engagement according to the new information. The preliminary level of the materiality is the maximum amount of distortion over the auditor believes that it can influence the users decisions. If the auditor sets a preliminary low level of the materiality it increases the confidence in the contents of the financial statements, but he have to collect more audit evidence.

It was made a comparation beetwen the two exercises on the evolution of the elements used in determining the materiality. There is a significant increase of the total assets in 2012 compared to 2011 , respectively 300.582 lei $(117.32 \%)$ due, especially to high growth of the receivable value; turnover increased slightly in 2012 with 41.913 lei (5.86\%); gross profit also increase in 2012 compared to 2011 with 23.148 lei (49.46\%).

Calculation of materiality for the financial statements in the phase of audit planning in accordance with ISA 320, "Materiality", is presented in table no. 3.

Tabel no. 3

\begin{tabular}{llll}
\multicolumn{3}{c}{ Materiality calculation } & \\
Total assets before deducting debts & $\mathbf{3 1 . 1 2 . 2 0 1 2}$ & $\mathbf{3 1 . 1 2 . 2 0 1 1}$ & Difference \\
$1 \%$ & 556.788 & 256.206 & \\
$2 \%$ & 5.568 & 2.562 & 3.006 \\
Turnover & 11.136 & 5.124 & 6.012 \\
& 757.182 & 715.269 & \\
& 28 & &
\end{tabular}




\begin{tabular}{llll}
$\mathbf{0 , 5 \%}$ & $\mathbf{3 . 7 8 6}$ & 3.576 & 210 \\
$1 \%$ & 7.572 & 7.153 & 419 \\
\hline Profit before tax & 69.950 & 46.802 & \\
$5 \%$ & 3.497 & 2.340 & 1157 \\
$10 \%$ & 6.994 & 4.680 & 2314 \\
\hline Materiality & $\mathbf{3 . 7 8 6}$ & & \\
\hline
\end{tabular}

Source: financial statements of the organization, authors view

In determining materiality at the planning stage it was took into account the proportion of $0.5 \%$ of turnover in 2012, which is a constant indicator in the last years and relevant for the users of the financial statements of the organization, resulting a level of materiality of 3.786 lei. The materiality was calculated according to turnover, because it was the most constant indicator in recent years. The total assets have experienced considerable variation as well as gross profit, which is why were not considered. The materiality heve be chosen according to the users and the audit report, which can be specifically interested by certain accounts from the profit and loss account. At the entities who are carrying out expenses such as ministries or government agencies, the basis for determining the materiality is the total level of spending while at the entities that collect revenue, the basis for determining materiality is the turnover.

Since the audit evidence are collected to the level of the transactions categories and accounts balances, is necessary that global materiality for the financial statements to be allocated on accounting cycles or on accounts included in the financial statements. The distribution of materiality in relation to account balances, classes of transactions and information presentation is performed as follows.

Table no. 4

The materiality distribution on transactions classes

\begin{tabular}{|l|c|c|}
\hline \multicolumn{1}{|c|}{ Indicators } & Percent & Lei \\
\hline Tangible and intangible assets & $10 \%$ & 379 \\
\hline Group accounts and investments & $5 \%$ & 189 \\
\hline Stocks & $5 \%$ & 189 \\
\hline Debtor & $10 \%$ & 379 \\
\hline Short-term investments & $5 \%$ & 189 \\
\hline Liquid amounts & $10 \%$ & 379 \\
\hline Creditors & $10 \%$ & 379 \\
\hline Sales & $10 \%$ & 379 \\
\hline Purchases & $10 \%$ & 379 \\
\hline Wages and salaries & $10 \%$ & 379 \\
\hline Management remuneration & $5 \%$ & 189 \\
\hline $\begin{array}{l}\text { Balance sheet and accounting records after } \\
\text { the end of exercise }\end{array}$ & $5 \%$ & 189 \\
\hline Transactions with related parties & $5 \%$ & 189 \\
\hline Total & $100 \%$ & 3.786 \\
\hline
\end{tabular}

Source: Alin Constantin Dumitrescu, 2010, p. 150, authors view

As a result of the adjustment of the annual financial statements with the accounting operations proposed by the auditor, occure the following modification: the volume of assets 
decreased based on the receivables due to the effect of reversal of invoices, in amount of 100.000 lei, unconfirmed by the customers and verified by the auditor through alternative procedures. The reversal invoices totaling 100.000 lei had the falowings results:

Reducing the receivable with 100.000 lei; sales and turnover with 100.000 lei;

Reducing the costs regarding the sales: if at an expence of 687.232 lei it was obtained a sale of 757.182 lei, it is resulting that the costs decreased with 90.762 lei $\left(100.000^{*}\right.$ 687.232/757.182).

$>$ The effect produced in the profit and loss account by the reversal sales with 100.000 lei has led to decrease earnings, part of the equity position from the balance sheet, with the amount of 9.238 lei (-1000.000 90762$)$;

$>$ Considering that were not sold goods at a cost of 90.762 lei, result that the that stocks increased with the amount of 90.762 lei.

Financial statements adjusting

\begin{tabular}{|l|c|c|}
\hline \multicolumn{1}{|c|}{ Indicators } & $\mathbf{3 1 . 1 2 . 2 0 1 1}$ & $\mathbf{3 1 . 1 2 . 2 0 1 2}$ \\
\hline Fixed assents & 63.895 & 59.618 \\
\hline Current assets, from which: & 192.311 & 487.932 \\
\hline$>$ stocks & 25.042 & 163.071 \\
\hline$>$ receivable & 156.240 & 317.064 \\
\hline \multicolumn{1}{|c|}{$>$ liquid assets } & 11.029 & 7.797 \\
\hline Total assets & 256.206 & 547.551 \\
\hline Liabilities & 204.746 & 437.901 \\
\hline Equity & 71.700 & 121.038 \\
\hline Turnover & 715.269 & 657.182 \\
\hline Sales cost & 668.467 & 596.470 \\
\hline Gross profit & 46.802 & 60.712 \\
\hline
\end{tabular}

Sursa: financial statements of the organization, authors view

Recalculation of materiality for the financial statements as a whole, due to financial statements adjustment is presented in table no. 6 .

Table no. 5 
According to the above analysis, it is observed that the turnover has the smallest variation, so it is chosen as recalculated materiality the amount of 3.286 lei.

Following the final discussions with the client, he does't recorded in the accouncy the following errors identified during the audit:

adjustments for fixed assets depreciation proposed to cassation: 2.000 lei;

taxes on unregistered income: 900 lei;

$>$ provision for restructuring (compensation for 2011): 1.000 lei

It is noted that the total amount of the errors (3.900 lei) exceeds the corrected materiality (3286 lei), although the amount of each error separately is below the materiality The more the total uncorrected information approaches the materiality level, the auditor should consider reducing the risk by implementing additional procedures or requires management to make corrections in the financial statements where they found errors. Following discussions with the client, he decided to proceed to the correction of errors detected by the auditor.

\section{Conclusions}

Viewed from the perspective of financial audit and implicitly the determination and analysis of materiality, between audit and accounting there is a close relationship in the sense that most part of the audit activity concerns accounting information.

To establish the materiality it is an aspect who concerns the auditor judgment and is influenced by the auditor's perception regarding the needs of financial information of the users of financial statements. Due to the complexity of elements that need to be considered, there are not specific recommendations for financial auditors in order to determining materiality. So auditors and organizations must establish their own guidelines that concerns one or more bases of comparison and a range of percentage values.

At the end of the mission, the auditor prepares a list of its findings including the examination of different objects regarding the audited organization. In case the organization will make the corrections suggested by the auditor, it may issue an unqualified opinion. If the organization refuses to accept the auditor suggestions, two situations may occur:

$>$ if its findings have not a significant character, the auditor will give a favorable opinion to the regularity and the sincerity of the annual accounts;

$>$ if the findings have significant character, the auditor should adopt one of the following solutions:

Qualified opinion. The auditor will indicate the items from the financial statements who make the object of his reserve and how these elements can be corrected and the influence that this correction will have on the annual accounts. If the reserves are too numerous, the auditor will refuse the certification of the regularity and the sincerity of the annual accounts.

Unfavorable opinion. Occurs in the situations in which the regularity and sincerity of the accounting and annual accounts are not representing a true, clear and complete image of the financial situation, results, assets.

Disclaimer of opinion. If the auditor appreciate that the organization has not made available sufficient information to enable him to establish his conclusions, he will recorded in his report that he is unable to issue an opinion.

Although establishing significant elements and materiality is important the determination method is purely subjective. The audit standards do not establish an absolute level or percentage and any mathematical formula universally applicable. Their establishment is on the auditor's judgment, because the numerous factors who must be taken into account and their relative importance. There are more important the auditor's experience, his professional preparation.

We believe that there should be specific rules for determining the materiality. The fact that its estabilish is an aspect who concern the auditor's judgment, can have subjective connotations. Moreover, at present, the materiality is set, usually as a percentage that is applied to a reference 
base, being considered certain minimum and maximum intervals which can vary significantly (for example between $5 \%$ and $10 \%$ of gross profit). Consequently we consider that it should be revised the method of determining the materiality, it is necessary to introduce regulations that specify exactly how to estabilish it. We propose that in determining materiality to be taken into account some limitations, as shown in table no. 7.

Reference bases proposal for materiality

\begin{tabular}{|c|c|c|c|}
\hline No. & Indicators & Materiality (\%) & Reference bases \\
\hline 1 & Turnover & $1 \%$ & If turnover $>200.000$ euro \\
\hline 2 & Turnover & $0,5 \%$ & If turnover $<200.000$ euro \\
\hline 3 & Gross profit & $10 \%$ & If gross profit $>100.000$ euro \\
\hline 4 & Gross profit & $5 \%$ & If gross profit $<100.000$ euro \\
\hline 5 & Total assets & $2 \%$ & If total assents $>50.000$ euro \\
\hline 6 & Total assets & $1 \%$ & If total assets $<50.000$ euro \\
\hline
\end{tabular}

Source: authors view

We also, propose to be established references bases applicable to any entity. Currently in different specialty papers appear different references bases, in some appearing as references bases turnover, total assets, gross profit, in others works are added equity, net profit etc. We propose that the references bases at private entities to be: turnover, total assets, gross profit because those reflects the most important elements of the financial statements of any entities independent of their activity.

\section{References}

1. Botez D., 2012. Capcanele pragului de semnificaţie şi provocări ale evaluării riscurilor, Revista Practici de Audit, nr. 1

2. Bunget O., 2010. Audit financiar, Timişoara, Editura Mirton

3. Domnişoru S., 2011. Audit statutar şi comunicare financiară, vol. 1, Bucureşti, Editura Economică

4. Dumitrescu A. C., 2010. Detectarea fraudelor şi erorilor în auditul financiar. Miză, oportunitate şi responsabilitate, Timişoara, Editura Mirton

5. Houghton K., Jubb C., Kend M., 2010. The future of auditing. Keeping Capital Markets Efficient, Towards a national strategy of the future of auditing, Canberra, The Australian National University Press

6. Popa I., Bunget O., Marcu N., 2011. Standarde generale de audit, Timişoara, Editura Mirton

7. Renard J., 2010. Theory and practice of internal audit, Paris, Eyrolle, Editions d Organisations

8. Toma M., 2009. Iniţiere în auditul situaţiilor financiare ale unei entităţi, ediţia a III-a revizuită şi adăugată, Bucureşti, Editura CECCAR

9. Todea N., Stanciu I., 2009. Studiu privind calculul pragului de semnificaţie în activitatea de audit financiar, Revista Audit Financiar, nr. 10/2009, pag. 42-49

10. Standardul International de Audit 320 "Pragul de semnificaţie în audit"

11. http://restant2012.cafr.ro/files/4513/6183/6457/mirela_paunescu_I.pdf

12. http://www.biblioteca-digitala.ase.ro/biblioteca/model/index 2.asp

13. http://www.cndi.ro/wp-content/uploads/2012/03/Unitatea_de_invatare_3.pdf

14. http://www.rasfoiesc.com/business/economie/ISA-Pragul-de-semnificatie-in-47.php 